\title{
CHEMICAL COMPOSITION AND ANTIMICROBIAL ACTIVITY OF THE ESSENTIAL OIL OF SATUREJA BIFLORA (LAMIACEAE)
}

\author{
Josphat C. Matasyoh ${ }^{\mathrm{a}^{*}}$, Joyce J. Kiplimo ${ }^{\mathrm{a}}$, Nicholas M. Karubiu ${ }^{\mathrm{b}}$ and Tiffany P. Hailstorks ${ }^{\mathrm{c}}$ \\ ${ }^{\mathrm{a}}$ Department of Chemistry, ${ }^{\mathrm{b}}$ Department of Animal Health, Egerton University, P. O. Box 536, \\ Njoro, Kenya \\ ${ }^{c}$ Department of Chemistry, Hampton University, Hampton, VA 23668. USA
}

(Received June 8, 2006; revised July 26, 2006)

\begin{abstract}
Hydro-distilled essential oil from Satureja biflora (Lamiaceae) growing in Kenya was analysed by gas chromatography mass spectrometry (GC-MS) and also evaluated for antimicrobial activity. Twenty two compounds which constitute $99.29 \%$ of the total oil were identified. The oil was dominated by monoterpenes, which accounted for $62.02 \%$ of the oil. This monoterpene fraction was characterized by a high percentage of linalool $(50.60 \%)$ such that this Satureja species can be classified as the linalool chemotype. The other major monoterpenes were $\alpha$-terpineol $(2.80 \%), \beta$-ocimene $(2.25 \%), \beta$-pinene $(1.96 \%)$ and cis-linalool oxide $(1.91 \%)$. Sesquiterpenes present in fairly good amounts are germacrene D (10.63\%), $\alpha$-cadinol (4.53\%), $\beta$-bourbonene $(2.33 \%), \delta$-cadinene $(2.19 \%), \tau$-cadinol $(2.17 \%)$, endo-1-bourbonanol $(2.14 \%)$ and $\beta$-caryophyllene $(1.98 \%)$. Aliphatic alcohols and acids accounted for $7.23 \%$ of the oil, of which the major one was linoleic acid (4.48\%). The oil was screened for antimicrobial activity against both gram-positive (Staphylococcus aureus, Bacillus ssp.) and gram-negative (Escherichia coli, Pseudomonas aeruginosa, Salmonella typhi, Klebsiella pheumoniae, Proteus mirabilis) bacteria and a pathogenic fungus (Candida albicans). To the best of our knowledge nothing concerning the chemical composition and biological activity of the essential oil of S. biflora has been reported.
\end{abstract}

KEY WORDS: Satureja biflora, Essential oil, Antimicrobial activity

\section{INTRODUCTION}

The genus Satureja is in the family of Lamiaceae and has about 30 species distributed in tropical Africa, Europe and North America. Oils obtained from the leaves and flowers of Satureja spp. have varied industrial applications as flavouring materials, medicine and perfumes [1].

Literature review showed variation between chemical compositions of different Satureja species oils. The main component of the oil of S. icarica, S. boissieri and S. pilosa from Turkey was carvacrol $(59.2 \%, 44.8 \%, 42.1 \%)$, respectively [2]. The main constituent of S. brownei [3] oil from Venezuela was found to be pulegone (64.3\%), while that of S. parvifolia [4] oil from Argentina is piperitone oxide. Germacrene D has been detected to be the main compound of $S$. coerulea [5]. The main components of S. mutica, S. macrantha and S. intermedia growing in Iran were found to be carvacrol (30.9\%), p-cymene (25.8\%) and thymol (32.3\%), respectively [6]. Essential oil from S. khuzistinica Jamzad growing widely in Iran contained $93.9 \%$ carvacrol [7].

Different Satureja species have been used in traditional medicine as antimicrobial, spasmolytic, analgesic, cicatrizing and diuretic agents. The antibacterial properties of several essential oils of S. montana [8] and S. thymbra [9] have been studied. The essential oils of $S$. obovata [10, 11], S. cuncifolia [5] and S. hortensis [12] have been evaluated as spasmolytic agents. S. biflora is a perennial shrub with white flowers, and is used to relieve headache in some communities in Kenya [13]. Little is known of the medicinal value of this particular species of Satureja. To the best of our knowledge nothing has been reported concerning the chemical composition and biological activity of the essential oil of S. biflora.

*Corresponding author. E-mail: matasyoh2001@yahoo.com; Fax: 00254-51-62405 
The purpose of this research was to study the chemical composition and biological effects of the oil of S. biflora. The research findings will contribute towards the use of this plant in herbal medicine and aromatherapy.

\section{EXPERIMENTAL}

\section{Plant material}

The leaves of $S$. biflora were collected from the Botanical-garden of Egerton University in Kenya which is at an altitude of $2127 \mathrm{~m}$. A voucher specimen (EU-1262) was deposited at the Department of Botany, Egerton University.

\section{Isolation of volatile components}

Fresh leaves of $S$. biflora were subjected to hydro-distillation in a Clevenger-type apparatus for a minimum of $4 \mathrm{~h}$. The essential oil was obtained in a yield of $0.2 \% \mathrm{w} / \mathrm{w}$ after drying over anhydrous $\mathrm{Na}_{2} \mathrm{SO}_{4}$.

\section{GC, GC-MS analysis}

Samples of essential oils were diluted in methyl-t-butylether (MTBE) (1:100) and analysed on an Agilent GC-MSD apparatus equipped with an Rtx-5SIL MS ('Restek') (30 m x 0.25 mm i.d., $0.25 \mu \mathrm{m}$ film thickness) fused-silica capillary column. Helium (at $0.8 \mathrm{~mL} / \mathrm{min}$ ) was used as a carrier gas. Samples were injected in the split mode at a ratio of 1:10 - 1: 100. The injector was kept at $250{ }^{\circ} \mathrm{C}$ and the transfer line at $280{ }^{\circ} \mathrm{C}$. The column was maintained at $50{ }^{\circ} \mathrm{C}$ for $2 \mathrm{~min}$ and then programmed to $260{ }^{\circ} \mathrm{C}$ at $5{ }^{\circ} \mathrm{C} / \mathrm{min}$ and held for $10 \mathrm{~min}$ at $260{ }^{\circ} \mathrm{C}$. The MS was operated in the EI mode at $70 \mathrm{eV}$, in $\mathrm{m} / \mathrm{z}$ range $42-350$. The identification of the compounds was performed by comparing their retention indices and mass spectra with those found in literature [14] and supplemented by Wiley and QuadLib 1607 GC-MS libraries. The relative proportions of the essential oil constituents are expressed as percentages obtained by peak area normalization, all relative response factors being taken as one.

\section{Pharmacological screening}

The antimicrobial activity of the essential oil was tested according to the National Committee of Clinical Laboratory Standards [15] against the following microorganisms: Staphylococcus aureus ATCC 25923, Escherichia coli ATCC 25922, Pseudomonas aeruginosa 27853, and clinical isolates Bacillus ssp., Salmonella typhi, Klebsiella pneumoniae, Proteus mirabilis, and candida albicans. Freshly grown microbial suspensions in Mueller Hinton Broth were standardized to a cell density of $1.5 \times 10^{8}$ (McFarland No. 0.5). Serial dilutions of the essential oil were done using $10 \%$ TWEEN 80 in distilled sterile water which was also used as the control. The essential oil was diluted to $11.1 \%, 12.5 \%, 14.3 \%, 16.7 \%, 20 \%, 25 \%, 33.3 \%$, and $50 \%$. Neat oil was also used giving a corresponding concentration of $75 \times 10^{2} \mu \mathrm{g}$ per sensitivity disc. The positive antibacterial and antifungal activities were established by the presence of measurable zones of inhibition after 24 hours of incubation at $37{ }^{\circ} \mathrm{C}$. Minimum inhibition concentration (MIC) was defined as the lowest concentration that inhibited growth of the microorganism detected visually. Chloramphenicol and nyastatin were used as standard antibiotics. 


\section{RESULTS AND DISCUSSION}

The chemical composition and antimicrobial activity of the essential oil of S. biflora is reported here for the first time. Table 1 lists twenty-two compounds identified by GC and GC-MS, which constitute $99.29 \%$ of the total oil. The oil was dominated by monoterpene hydrocarbons which accounted for $62.02 \%$ of the oil. This monoterpene fraction was characterized by a high percentage of linalool $(50.60 \%)$ such that this Satureja species can be classified as the linalool chemotype. Considering components with concentrations of about $2 \%$ and above, the other major monoterpenes were $\alpha$-terpineol $(2.80 \%)$, $\beta$-ocimene $(2.25 \%), \beta$-pinene $(1.96 \%)$ and cislinalool oxide $(1.91 \%)$. The main sesquiterpene component was germacrene D $(10.63 \%)$. Other sesquiterpenes present in appreciable amounts were $\alpha$-cadinol $(4.53 \%), \beta$-bourbenene $(2.33 \%)$, $\delta$-cadinene $(2.19 \%), \tau$-cadinol $(2.17 \%)$, endo-1-bourbonanol $(2.14 \%)$ and $\beta$-caryophyllene $(1.98 \%)$. The aliphatic hydrocarbons represent only $7.23 \%$ of the oil, of which $4.48 \%$ was linoleic acid.

Table 1. Chemical composition of Satureja biflora leaf oil

\begin{tabular}{|c|c|c|c|c|}
\hline No. & Compound & KI & $\begin{array}{c}\text { Concentration } \\
\%\end{array}$ & $\begin{array}{l}\text { Method of } \\
\text { identification }\end{array}$ \\
\hline \multicolumn{5}{|c|}{ Monoterpenes } \\
\hline 1. & Sabinene & 976 & 0.49 & RI, GC-MS \\
\hline 2. & $\beta$-Pinene & 978 & 1.96 & RI, GC-MS \\
\hline 3. & $\beta$ - Ocimene & 1050 & 2.25 & RI, GC-MS \\
\hline 4. & cis-Linalool Oxide & 1072 & 1.91 & RI, GC-MS \\
\hline 5. & trans-Linalool oxide & 1089 & 1.49 & RI, GC-MS \\
\hline 6. & Linalool & 1098 & 50.60 & RI, GC-MS \\
\hline 7. & Terpinen-4-ol & 1177 & 0.52 & RI, GC-MS \\
\hline \multirow[t]{2}{*}{8.} & $\alpha$-Terpineol & 1191 & 2.80 & RI, GC-MS \\
\hline & $\begin{array}{l}\text { Total } \\
\text { Sesquiterpenes }\end{array}$ & & 62.02 & \\
\hline 9. & $\beta$ - Bourbonene & 1384 & 2.33 & RI, GC-MS \\
\hline 10. & $\beta$ - Elemene & 1393 & 0.72 & RI, GC-MS \\
\hline 11. & $\beta$-Caryophyllene & 1430 & 1.98 & RI, GC-MS \\
\hline 12. & $\beta$ - Farnesene & 1458 & 0.59 & RI, GC-MS \\
\hline 13 & Germacrene D & 1487 & 10.63 & RI, GC-MS \\
\hline 14. & $\delta$-Cadinene & 1524 & 2.19 & RI, GC-MS \\
\hline 15. & Nerolidol & 1566 & 1.02 & RI, GC-MS \\
\hline 16. & Endo-1-bourbonanol & 1570 & 2.14 & RI, GC-MS \\
\hline 17. & Caryophyllene oxide & 1582 & 1.74 & RI, GC-MS \\
\hline 18. & $\tau$-Cadinol & 1641 & 2.17 & RI, GC-MS \\
\hline \multirow[t]{3}{*}{19.} & $\alpha$-Cadinol & 1653 & 4.53 & RI, GC-MS \\
\hline & Total & & 30.04 & \\
\hline & Aliphatic alcohols and acids & & & \\
\hline 20. & 1-Octen-3-ol & 979 & 1.13 & RI, GC-MS \\
\hline 21. & Palmitic acid & 1970 & 1.62 & RI, GC-MS \\
\hline \multirow[t]{3}{*}{22.} & Linoleic acid & 2030 & 4.48 & RI, GC-MS \\
\hline & Total & & 7.23 & \\
\hline & Total percentages & & 99.29 & \\
\hline
\end{tabular}

The essential oil was evaluated for antimicrobial activity against pathogenic strains of grampositive ( $S$. aureus, Bacillus ssp) and gram-negative (E. coli, P. aeruginosa, S. typhi, K. pneumoniae, $P$. mirabilis) bacteria. It was found to be active against all the bacteria strains 
except for $P$. aeruginosa. It also showed a marked anti-fungal activity against $C$. albicans. $P$. aeruginosa is less susceptible to the antimicrobial properties of essential oils than many bacteria and its tolerance is considered to be due to its outer membrane [16]. The activity of the oil varies with its concentration and kind of bacteria. These differences in the susceptibility of the test organisms to essential oil could be attributed to variation in the rate of monoterpene penetration through cell wall and cell membrane structures. The ability of essential oil to disrupt the permeability barrier of cell membrane structures and the accompanying loss of chemiosmotic control is the mostly likely source of its lethal action [17].

Although the concentrations of the oil were generally in the range of 100 times more than the standard antibiotic (Chloramphenicol), they showed marked antibacterial and antifungal activities as evidenced by their zones of inhibition (Table 2). This difference in concentrations of the essential oil and the standard antibiotic can be explained in terms of the fact that the active components in the oil comprise of only a fraction of the oil used. Therefore, the concentration of the active components could be much lower than the standard antibiotics used. Among the gram-negative bacteria, the oil was much active against $S$. typhi. The activity response to $S$. typhi was three times more at $75 \times 10^{2} \mu \mathrm{g}$ as that of chloramphenicol $(30 \mu \mathrm{g})$. The inhibition zones of the neat oil against gram-positive bacteria compared very well with those of the standard antibiotic. The oil showed relatively similar activity across the concentration range to E. coli and P. mirabilis.

Table 2A. Antimicrobial activity of the oil of Satureja biflora.

\begin{tabular}{|c|c|c|c|c|c|c|c|c|c|c|}
\hline \multirow{2}{*}{\multicolumn{2}{|c|}{ Micro-organism }} & \multicolumn{9}{|c|}{ Inhibition zone $(\mathrm{mm})$} \\
\hline & & \multicolumn{9}{|c|}{ Essential oil $\mu \mathrm{g} \mathrm{x} 10^{2}$} \\
\hline $\begin{array}{l}\text { Gram } \\
\text { negative } \\
\text { bacteria }\end{array}$ & Source & 75.0 & 37.5 & 25.0 & 18.8 & 15.0 & 12.5 & 10.7 & 9.4 & 8.3 \\
\hline E. coli & $\begin{array}{l}\text { ATCC } \\
25922\end{array}$ & $15 \pm 0$ & $14 \pm 0$ & $13 \pm 0.5$ & $12 \pm 2.0$ & $11 \pm 1.0$ & $10 \pm 1.0$ & $9 \pm 0.5$ & $8 \pm 1.0$ & $7 \pm 0$ \\
\hline S. typhi & ${ }^{\mathrm{a}}$ KEMRI & $31 \pm 0.5$ & $15 \pm 2.5$ & $14 \pm 1.0$ & $12 \pm 0.5$ & $10 \pm 0$ & $9 \pm 0.5$ & 0 & 0 & 0 \\
\hline $\begin{array}{l}\text { K. } \\
\text { pneumoniae }\end{array}$ & ${ }^{\mathrm{a}} \mathrm{KEMRI}$ & $12 \pm 0.5$ & $11 \pm 0.5$ & $9 \pm 0.5$ & 0 & 0 & 0 & 0 & 0 & 0 \\
\hline P. mirabilis & ${ }^{\mathrm{a}} \mathrm{KEMRI}$ & $15 \pm 0$ & $14 \pm 0.5$ & $13 \pm 0.5$ & $12 \pm 0$ & $11 \pm 0.5$ & $10 \pm 0$ & $9 \pm 1.0$ & $8 \pm 1.0$ & $7 \pm 0.5$ \\
\hline $\begin{array}{l}P . \\
\text { aeruginosa }\end{array}$ & \begin{tabular}{|l|} 
ATCC \\
27853 \\
\end{tabular} & 0 & 0 & 0 & 0 & 0 & 0 & 0 & 0 & 0 \\
\hline \multicolumn{11}{|c|}{ Gram positive bacteria } \\
\hline S. aureus & \begin{tabular}{|l|l|} 
ATCC \\
25923 \\
\end{tabular} & $24 \pm 0$ & $20 \pm 0$ & $14 \pm 0.5$ & $12 \pm 1.0$ & $11 \pm 2.0$ & $10 \pm 0.5$ & $10 \pm 0.0$ & $8 \pm 0.5$ & 0 \\
\hline Bacillus spp. & ${ }^{a}$ KEMRI & $34 \pm 2$ & $32 \pm 1.0$ & $22 \pm 1.0$ & $17 \pm 1.5$ & $12 \pm 1.0$ & $10 \pm 1.0$ & $9 \pm 1.0$ & 0 & 0 \\
\hline \multicolumn{11}{|l|}{ Fungus } \\
\hline $\begin{array}{l}\text { Candida } \\
\text { albicans }\end{array}$ & ${ }^{\mathrm{a}} \mathrm{KEMRI}$ & $15 \pm 0$ & $12 \pm 0$ & $11 \pm 0.5$ & $10 \pm 0$ & $9 \pm 0.5$ & $7 \pm 1.0$ & 0 & 0 & 0 \\
\hline
\end{tabular}


Table 2B. Antimicrobial activity and MIC for the essential oil and standard.

\begin{tabular}{|c|c|c|c|c|c|}
\hline \multicolumn{2}{|c|}{ Micro-organism } & \multicolumn{4}{|c|}{ Inhibition zone (mm) } \\
\hline & & STD $^{b}$ & & \multicolumn{2}{|c|}{$\mathrm{MIC} \mathrm{mg} / \mathrm{mL}$} \\
\hline $\begin{array}{l}\text { Gram } \\
\text { negative } \\
\text { bacteria }\end{array}$ & & $30 \mu \mathrm{g}$ & Control & $\mathrm{EO}^{\mathrm{c}}$ & STD $^{b}$ \\
\hline E. coli & ATCC 25922 & $28 \pm 1.5$ & 0 & 83.3 & 25 \\
\hline S. typhi & ${ }^{a}$ KEMRI & $10 \pm 1.0$ & 0 & 125.0 & 25 \\
\hline $\begin{array}{l}\text { K. } \\
\text { pneumoniae }\end{array}$ & ${ }^{\mathrm{a}} \mathrm{KEMRI}$ & $25 \pm 0$ & 0 & 250.0 & 22.5 \\
\hline P. mirabilis & ${ }^{\mathrm{a}} \mathrm{KEMRI}$ & $8 \pm 0$ & 0 & 83.3 & 0 \\
\hline $\begin{array}{l}P . \\
\text { aeruginosa }\end{array}$ & ATCC 27853 & 0 & 0 & 0 & 0 \\
\hline \multicolumn{6}{|c|}{ Gram positive bacteria } \\
\hline S. aureus & ATCC 25923 & $24 \pm 1.0$ & 0 & 93.8 & 31.3 \\
\hline Bacillus spp. & ${ }^{\mathrm{a}}$ KEMRI & $26 \pm 2.0$ & 0 & 107.0 & 26.3 \\
\hline Fungus & & $\begin{array}{c}\text { Nyastatin } 30 \\
\mu \mathrm{g}\end{array}$ & & & \\
\hline $\begin{array}{l}\text { Candida } \\
\text { albicans }\end{array}$ & ${ }^{\mathrm{a}} \mathrm{KEMRI}$ & $10 \pm 0.5$ & 0 & 125 & 0 \\
\hline
\end{tabular}

a - Kenya Medical Research Institute, b - Chloramphenicol, c - Essential oil.

The minimum inhibition concentration (MIC) of oil for gram-negative bacteria ranged from 83.3 to $250 \mathrm{mg} / \mathrm{mL}$ and 93.8 to $107 \mathrm{mg} / \mathrm{mL}$ for gram-positive bacteria. The MIC for the fungus C. albicans is $125 \mathrm{mg} / \mathrm{mL}$. The MIC values for chloramphenicol range from 22.5 to 31.3 $\mathrm{mg} / \mathrm{mL}$. In general, the oil showed greater antibacterial activity than antifungal activity (see Table 2).

Linalool, the major component in this study, has been found to have antimicrobial activity against various microbes except for P. aeruginosa [18]. Linalool is also known to inhibit spore germination and fungal growth. The inhibition of sporelation appeared to arise from respiratory suppression of aerial mycelia [19].

$\alpha$-Terpineol, which occurs in appreciable amounts in this oil, has been reported to inhibit the growth of quite a number of bacteria and fungi $[18,20]$. Other compounds present in the oil though in minor concentration have previously been known to possess antimicrobial properties. These include $\beta$-caryophyllene, a common sesquiterpene widely distributed in plants, which possesses anti-inflammatory and anticarcinogenic activities [21]. Its oxygenated form caryophyllene oxide is known to possess antimicrobial properties against a wide range of bacteria and fungi [22]. Terpinen-4-ol is present in a minor quantity of $0.52 \%$, but it is known to have a broad spectrum activity against micro-organisms [16].

Linoleic acid, which is one of the major constituents of the oil under study, is known as an essential fatty acid in human health. As a polyunsaturated fatty acid, linoleic acid helps lower the ratio of low density lipoproteins (LDLs) to high density lipoproteins (HDLs). It is also known to have a high antimicrobial activity [23].

\section{AKNOWLEDGEMENTS}

The authors are thankful to Prof. Uzi Ravid of Newe Yaár Centre in Israel for making available the GC-MS apparatus for this work. 


\section{REFERENCES}

1. Teklu, S.; Alemayehu,G.; Abegaz, B.M. J. Essent. Oil Res. 1998, 10, 339.

2. Azaz, D.; Demirci, F.; Kurcuoglu, M.; Tumen, G.; Baser, K.H.C. Z. Naturforsch. 2002, $57 \mathrm{c}, 817$.

3. Rojas, L.B.; Usubillaga, A. Flavour Fragr. J. 2002, 15, 21.

4. Viturro, C.I.; Molina, A.; Guy, I.; Charles B.; Guinaideau, H.; Fournet, A. Flavour Fragr. J. 2000, 15, 377.

5. Tumen, G.; Baser, K.H.C.; Demirci, B.; Ermin, N. Flavour Fragr. J. 1998, 13, 65.

6. Sefidkon, F.; Jamzad, Z. Food Chem. 2005, 91, 1.

7. Farsam, H; Amanlou, M; Radpour, M.R.; Salehinia, A.N.; Shafiee, A Flavour Fragr. J. 2004, 19, 308.

8. Melegari, M.; Albasini, A.; Provvisionato, A.; Bianchi, A.; Vampa, G.; Pecorari, P.; Rinaidi, M. Fitoterapia. 1985, 56, 85.

9. Capone, W.; Mascia, C.; Spanedda, L.; Chiappini, M. Fitoterapia. 1989, 60, 90.

10. Navarro, C.; Zazuelo A.; Jimenez, J.; Duarte J.; Quevedo, J. Fitoterapia. 1989, 60, 277.

11. Cruz, T.; Cabo, M.M.; Jimenez, J.; Zarzuelo, A. Fitolerapia. 1990, 61, 247.

12. Hajhashemi, V.; Sadraei, H.; Ghannadi, A.R.; Mohseni, M. J. Ethnopharmacol. 2000, 71, 187.

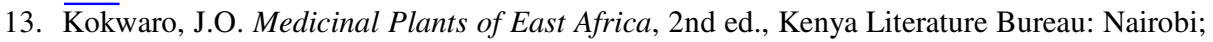
1993; pp 121-124.

14. Adams, R.P. Identification of Essential Oil Components by Gas Chromatography/Mass Spectroscopy, Allured Publishing Corporation: Illinois, U.S.A.; 1995.

15. National Committee for Clinical Laboratory Standards. Performance standards for antimicrobial disk susceptibility tests. Approved standard M2-A6. Wayne, Pa: National Committee for Clinical Laboratory Standards; 1997.

16. Cox, S.D.; Mann, C.M.; Markham, J.L.; Gustafson, J.E.; Warmington, J.R.; Wyllie, S.G. Molecules 2001, 6, 87.

17. Cox, S.D.; Mann, C.M.; Markham, J.L.; Bell, H.C.; Gustafson, J.E.; Warmington, J.R.; Wyllier, S.G. J. Appl. Microbiol. 2000, 88, 170.

18. Carson, C.F.; Riley, T.V. J. Appl. Bacteriol. 1995, 78, 264.

19. Lahlou, M.; Berrada, R. Pharm Biol. 2001, 141, 207.

20. Raman, A.; Weir, U.; Bloomfield, S.F. Lett. Appl. Microbiol. 1995, 21, 242.

21. Tellez, M.R.; Canel, C.; Rimando, A.M.; Duke, S.O. Phytochem. 1999, 52, 1035.

22. Guillen, M.D.; Cabo N.; Burillo, J. J. Sci Food Agric. 1996, 70, 359.

23. Manning, R.; Harvey, M. Aust. J. Exp. Agric. 2000, 42, 217. 